DOI: 10.20472/TEC.2019.008.022

\author{
ANNA POLEDNÁKOVÁ \\ University of Economics in Bratislava, Faculty of Business Management, Department of Business Finance, \\ Slovakia

\section{UNIVERSITY TEACHING METHODS AND FINANCIAL LITERACY}

\begin{abstract}
:
Education and general literacy are one of the basic pillars of the company. Analyzes showed us that financial literacy in Slovakia is very low. According to recent analyzes, primary and secondary school pupils have low financial literacy. A similar situation exists in universities. Economic trends prepare students for corporate financial management, who should have significantly better results in financial literacy than non-financial specializations, but this has not been confirmed in the analyzes. It is therefore necessary to find new teaching methods that will increase financial literacy and will increase students' motivation to increase financial literacy as a basis for further study of the financial subjects of the Financial Management program to be able to apply financial management tools and methods in the company.
\end{abstract}

\title{
Keywords:
}

financial literacy, financial market, financial management, teaching methods, indebtedness, bankruptcy.

JEL Classification: $121, \mathrm{G} 32$ 


\section{Introduction}

The current period in which we live is influenced by the rapid growth of knowledge. The penetration of science and technology changes the position of man, where the main role is played by decision-making based on the information obtained.

Over the course of several decades, there have been major changes in our country. We have achieved much greater freedom, but this is also associated with increased responsibility. In today's world, almost all of our decisions are influenced by money. A change in the behavior of the company is also noticeable. People are less conservative in terms of finance, are consuming faster and are more willing to borrow. We are surrounded by an increasing number of financial products and services, as well as ads that try to alert us to individual products. Insufficient knowledge can get us into financial problems much easier, and therefore the topic of financial literacy is increasingly topical. Institutions dealing with this issue are also aware of its importance.

Nowadays, finance is part of our everyday life and we need to be educated in this area. Financial literacy is therefore a very topical issue that is being addressed by an increasing number of public and private institutions. A large number of programs and projects are being set up to support financial education and achieve a better level of financial literacy.

Financial literacy and financial education can be seen as a modern term that seeks to help people navigate the financial markets, personal finance, etc., as people often get into credit problems by choosing for them. disadvantageous conditions, which they realize only when insolvency occurs. Education and general literacy are one of the fundamental pillars of society. In Slovakia, students can study in various institutions, whether they are state or private institutions. Education itself began in the early days of our history and evolved gradually with the advent of new technologies and company requirements. With the advent of computer technology, the concept of computer literacy has emerged and is gradually being put into practice.

The advent of computer technology meant for many people further education, training for the elderly is still problematic work with computer technology. Financial education is a new area of education. Many citizens find it difficult to orientate themselves in the field of finance, banking, there are many banking products and many different financial services, which means the need to educate students in this area from primary school to university. Financial education in Europe was addressed even before the crisis, but the growing crisis has brought major changes in financial markets and new financial issues, which has given greater incentives for the European Union institutions to improve the financial literacy of the population. Studies have shown that consumers are unable to assess which of the existing options are most effective for them, that the information they encounter is often incomprehensible to consumers. It also points out that young people's education is most needed, especially students.

Financial literacy is a set of knowledge, skills and value attitudes of a citizen needed to financially secure himself and his family in contemporary society and actively participate in the market of financial products and services. A financial literate citizen is money and priced and is able to responsibly manage the personal / family budget, including the management of financial assets and financial liabilities with respect to changing life situations.

The analysis of financial literacy of university students in Slovakia was carried out through a questionnaire survey. The questionnaire contained 24 questions, both open and closed. Students could complete the questionnaire via the Internet. Of the total number of completed questionnaires, 695 were completed by women and 219 by men. All three study levels were 
represented. The share of economic focus in the survey was $36 \%$, the other subgroups accounted for $64 \%$. Based on the weighted average, respondents answered $53.46 \%$ of the questions correctly. The financial literacy of respondents was lower than the survey carried out by the Slovak Banking Association in 2007, where they responded correctly to 66\%. For comparison, although on a smaller sample of respondents, the financial literacy of foreign university students was evaluated, their financial literacy reached $70.37 \%$. The financial literacy of undergraduates in economics was $58.5 \%$ of the survey, while the financial literacy of undergraduates studying noneconomic fields was $50.57 \%$. The fact that students in economic fields have a higher financial literacy stems from the fact that they encounter financial concepts more often.

In terms of gender, higher financial literacy is $57 \%$ for men and $52 \%$ for women. The difference between men and women in terms of economic focus is $58 \%$ and $59 \%$. The difference in financial literacy between men and women of the non-economic sector was significantly higher, with $55 \%$ men and $49 \%$ women. Compared to other cheerful countries, we are lagging behind in financial literacy.

The conclusion that financial literacy needs to be increased at higher education levels is also needed. Teaching should differ in the fields of economic and non-economic education. because the level of financial literacy of our university students is low

While the results of recent descriptive studies on financial literacy studies show a significantly lower level of financial literacy in Central and Eastern European countries compared to more developed countries. One of the reasons for the low financial literacy of university students is the fact that primary and secondary school pupils are lagging behind in financial literacy. In an international comparison of financial literacy levels in 2015, Slovak teenagers achieved belowaverage placement compared to peers from other countries. "More than one-third of pupils are in the risk group, ie $34.7 \%$ of our pupils are not able to solve and apply financial issues and problems in their basic contexts," said the Ministry of Education report on PISA 2015 results. achieved significantly worse results than in the previous PISA measurement. According to the Ministry of Education, the reason for the poor results of pupils is the way of teaching. It takes place at elementary and secondary schools cross-sectional - teachers of mathematics, Slovak or social science associate the subject matter with financial issues on their subjects.

Low levels of financial literacy have different consequences. Some may be less serious, others may get us in big trouble. For example, because of the lack of financial knowledge, we use disadvantageous financial products and services, although there are many more suitable alternatives on the market. Many people do not have an overview of their financial situation, they do not know their income and expenses, and because of inefficient financial planning they may find themselves in an unfavorable situation. But there are much more serious consequences of financial illiteracy. The low level of financial literacy is even considered to be one of the main causes of the 2008 financial crisis, mainly in the US. In the Slovak Republic, the problem of financial literacy is considered to be the increasing indebtedness of households, but also of businesses, non-payment of receivables and distraints imposed on the assets of individuals and legal entities. With the growth in financial products and the rapid development of the financial market, greater emphasis has been placed on the financial education of business managers and citizens alike. Awareness of how to navigate the world of finance, how to make the right financial decisions is needed from an early age.

The main cause of financial illiteracy is the lack of education in the area and lack of information. There are individual groups of the population who are financially backward and illiterate for 
various reasons. A number of factors have an impact on their financial education. The environment in which they live, the social roles they play, their jobs, health and more. But there are also people who have a positive impact on the environment, but the current development of society is so fast that they cannot navigate the new and new information flow. In financial illiteracy, the causes are different, the consequences in most cases the same, in all cases very stressful for a person. Financial literacy is reflected mainly in the management of our finances. Lack of information in lending and borrowing leads to debt problems, which can lead to social exclusion.

Financial literacy is also given by the economic situation and the economic situation is related to the political situation. Problems with orientation in financial services are probably rooted in the past and are related to the political past of our country. Among the causes of illiteracy, we can include the family as an institution, but also the rapid development of society.

Although the issue of financial education also began to be discussed in Slovakia, the result was that the Government of the Slovak Republic by Resolution no. 447 of 2 July 2008 approved the Proposal for a Strategy for Financial Education and Personal Finance Management, the results show that the financial literacy situation of pupils and students is not improving.

\section{Teaching methods and financial literacy}

The Faculty of Business Management is one of the faculties of the University of Economics in Bratislava, which provides university education with a focus on the preparation of managers and economists for the business and business sectors. The Financial Management study program enables students to acquire knowledge especially in the field of business economics and corporate finance so that they can apply the tools and methods of financial management in the company.

The trend of globalization brings new impetus for business growth and higher efficiency based on the territorial allocation of resources, which provides the best appreciation of invested capital, while allowing businesses to implement their strategic plans in an international context. The biggest breakthrough in the globalization process in the financial markets was the radical changes associated with the financial system and information technology, as well as free trade efforts. The financial markets have undergone significant financial innovations, resulting in the emergence of new financial instruments, such as derivatives. Globalization is linked to other trends in financial markets, namely securitization, institutionalization and intellectualization. The consequences of globalization are manifested in many areas of life (economic, legal, cultural, political and others), although they are most visible in the economic field. On the one hand, new opportunities are created for businesses, and on the other hand risks arise that need to be managed.

At the same time, globalization is increasing competition, creating a highly competitive environment to which all market participants are exposed. The high volatility of financial market conditions also brings new dimensions of space and time to business. As a result of the use of new information technologies, the mobility of production factors and products is increasing. The ability of the company to adapt to the current situation allows it to be flexible and to create the conditions for fulfilling the basic objective of the company - making a profit and increasing the market value of the company. Financial managers must concentrate on raising funds in the global financial markets for the purpose 
As the financial market conditions are constantly changing and businesses are exposed daily to the various risks affecting them, the financial strategy requires considerable flexibility and responsiveness to changes in external and internal conditions. As the financial situation of an undertaking is too important, its positive development and stability must be ensured in order not to jeopardize the company's future and fulfill all its main objectives and functions.

The functioning of the financial market as a source of information, the use of financial instruments in a global and turbulent environment is essential for businesses to remain competitive. Success in this respect is conditioned by quality information, knowledge and rational behavior of financial market participants.

Financial management can be characterized as managing the financial processes of a company in market economy conditions, it is an integral part of the management system of each business entity. Financial management is characterized by two basic functions: fund raising and investing. The first function is known as financial decision making and involves raising funds from both internal and external sources at the lowest cost. The investment decision is focused on the allocation of these funds over time and in ways that allow shareholders to maximize their wealth. The correlation between investment and financial decisions is very close and only the right combination of these decisions will maximize the value of the business as well as the value of the shareholder.

Financial management, understood as organizing and managing financial processes, is characterized by four basic activities:

- financial planning,

- financial decision-making,

- organization of financial processes,

- financial analysis and control.

Ultimately, all decisions, as well as processes taking place in an enterprise, will always be reflected in some way in costs or revenues and thus in financial results. Therefore, financial management is the unifying factor of the whole business management system. In addition, financial management is practically an art associated with the personality of a financial manager.

The task of raising capital for a business entity is complex because it implies knowledge of the economic environment (domestic, foreign, global) in which the company operates, as well as of the situation on the financial markets (domestic, foreign). The changes that have been made over the last three decades are mainly related to the speed and way in which cash flows through the global financial system, as well as to the growth and number of new techniques and instruments in the financial markets. The organization of the financial system, which is characterized by the interconnection of financial markets, has also changed.

With regard to trends in the financial markets as well as the financial crisis, financial management must respond to the impulses that come from the external environment as a result of the globalization of the economy. Financial managers need to adapt their decisions so that the business fulfills its goal, but also addresses new issues and problems arising from the globalization process, which have a major impact on the management of financial processes.

Businesses consider the financial market as a source of financing for their activities. By issuing shares and bonds, they acquire long-term capital, which is often greater than the bank's credit facilities in relation to a given entity. From the perspective of the source of financing, the financial 
market is traditionally understood. In developed countries, the importance of financial markets is growing as a source of information that serves managers and investors for financial management and decision making. Information from the financial markets represents the expected future development of the economy as a whole and also of individual companies. The absence of information from the local market may be replaced by appropriate data from other, mature financial markets.

The role of financial managers is to obtain funding sources and to decide on their effective placement, but also to monitor and evaluate ongoing financial processes. The quantification of the average cost of capital (or cost of equity and cost of capital) is used mainly by:

- assessing the effectiveness of investment projects;

- determination of optimal capital structure,

- EVA evaluation of business efficiency;

- valuation of the company by the yield method.

In the context of the teaching process, concepts such as modernization, efficiency, rationalization and optimization of teaching are increasingly associated. Modernization is not only a technique in teaching but also a modernization of educational content, teaching methods and organizational forms of teaching. Efficiency means in the shortest possible time, with the least effort of teachers and pupils to achieve the best educational results. Naturally, it is not just a sudden but also a sophisticated choice of teaching methods.

The ways of education that can currently be applied in the teaching process at the University of Economics vary. However, the most common and at the same time most used is conventional traditional teaching offered at all types of universities. These are mainly lectures, seminars, laboratory exercises, dialogues, excursions, study in libraries or research centers.

The lecture is a form of university education, through which the teacher provides information on the subjects and phenomena of reality generalized from individual scientific disciplines arranged in a coherent system. The aim of the lecture is also to clarify the methodological foundations of the relevant science. The lecture introduces not only the system, but also the methods of exploring, understanding and acquiring the curriculum. The lecture should stimulate the activity of the students by making both the content and its arrangement compel to reflect on the problems, not only during but also after the lecture. Seminar is a form of teaching that complements the lectures. It is based on the active participation of students in order to acquire and deepen the relevant knowledge and skills. In seminars, students present their work results, discuss the topics. Exercise is a form of teaching that is used to perform a particular activity in a controlled way by a learning subject. The aim is to consolidate knowledge and create skills. The content of exercises is related to the objectives of the subject and the profile of the graduate. Practice is understood as gaining some experience. Professional practice is one of the forms of higher education, completing the profile of graduates in terms of vocational, qualification and educational. It builds on theoretical and practical training. It contributes to the development of theoretical knowledge and the acquisition of basic professional skills necessary for active independent and creative work.

However, there are also innovative, unconventional and modern forms and methods of teaching that are poorly practiced due to their demanding preparation and implementation by students and 
teachers. These are methods that simulate practice and students have the opportunity to practically verify their theoretical knowledge.

Cooperative teaching. It is one of the most modern forms of teaching we know today. Its essence is that students work in small groups and acquire knowledge, solve tasks, perform practical tasks. Their evaluation depends on the performance of the whole group. The essence is the work of students of the whole group in smaller study groups, where they solve tasks.

Project teaching - is based on the ideas of humanization and democratization of teaching and also provides curriculum for experiential learning. Usually it combines knowledge from several subjects with a certain topic. Projects are handled in a small group according to pre-agreed rules. The result is work with practical transmission.

Problem teaching consists in creating problematic situations or tasks and managing students' activities while solving problem tasks more or less independently. The student gains experience from creative activities during the lessons, creative knowledge acquisition takes place. The teacher engages students in the process of finding solutions to problems, thereby gaining experience from creative activities.

The forms of education will continue to change, but schools will have to invest considerable resources in them to educate students for the knowledge society, the time we live. Therefore, higher education institutions need to provide students with knowledge and skills in a way that is accepted and required by the 21 st century.

\section{Conclusion}

Nowadays, finance is part of our everyday life and we need to be educated in this area. Financial literacy is therefore a very topical issue that is being addressed by an increasing number of public and private institutions. Financial literacy and financial education can be seen as a modern term that seeks to help people to navigate the financial markets, personal finance, etc., as people often run into financial problems. Analyzes have shown that financial literacy is low for all categories. As far as university students are concerned, there is no big difference between economic and non-economic fields. Therefore, it is essential to pay attention to new methods of teaching financial management so that graduates can, on the one hand, tackle the difficult financial difficulties of businesses in raising and allocating capital, and on the other hand that residents have an interest and incentive to higher financial literacy in order to avoid the financial problems with high indebtedness and insolvency.

\section{$4 \quad$ References}

DUBEŇOVÁ, K. (2011). Význam a potreba vzdelávania $v$ procese budovania dôslednej finančnej vedomosti. In Finančná gramotnost' ako súčast' ekonomického vzdelávania. Bratislava : Katedra pedagogiky NHF EU, 2011. ISBN 978-80-225-3249-5. s. 31-36.

HARAUSOVÁ H. (2011). Ako aktivujúco vyučovat' odborné predmety. Metodicko-pedagogické centrum v Bratislave, ISBN 978-80-8052-396-1

HLAVATÝ, I. (2011). Podpora finančnej gramotnosti v krajinách EÚ. In Finančná gramotnost' ako súčast' ekonomického vzdelávania. Bratislava: Katedra pedagogiky NHF EU, 2011. ISBN 978-80-225-32495. s. 47-50. 
HVOZDENSKÁ, J. (ed.). Finanční gramotnost: workshop. 1. vyd. Telč: Masarykova univerzita, 2013. ISBN 978-80-210-6365-5.

KRÁL'OVIČ, J. - VLACHYNSKÝ, K. (2011). Finančný manažment. 3. vyd. Bratislava: lura Edition, 2011. 468 s. ISBN 978-80-8078-356-3.

PIOVARČIOVÁ, V. (2008). Finančná gramotnost' - podmienka rozvoja kapitálového trhu. In Ekonomické znalosti pro tržní praxi. 1. vyd. Uherské Hradiště : Lešingrová Romana, 2008. ISBN 978-80-8727300-5. s. 506-509.

ŠRENKEL, L' - SMORADA, M. (2014). EVA ZERO - skutočná relatívna EVA. In Finančný manažér: periodikum Slovenskej asociácie podnikových finančníkov. Bratislava: Slovenská asociácia podnikových finančníkov, 2014. ISSN 1335-5813, 2014, roč. 14, č. 1, s. 15-21.

ZAŤKOVÁ, T. et al. (2015). Vybrané kapitoly z vysokoškolskej pedagogiky. SPU Nitra, ISBN 978-80-5521437-5.

file:///C:/Users/T470/Desktop/podklady\%20viedeň/Na\%20vysokých\%20školách\%20dominuje\%20pasívne\% 20vyučovanie\%20-\%20Denník\%20N.html

http://www.sbaonline.sk/financne-vzdelavanie/

file://C:/Users/T470/Desktop/Wiedeň/mereni-urovne-financni-gramotnosti-2601.htm

file:///C:/Users/T470/Desktop/Wiedeň/mereni-urovne-financni-gramotnosti-2784.htm

Národný štandard finančnej gramotnosti, verzia 1.0, www.mpcedu.

sk/library/files/narodnystandard.pdf, [cit. 26.12.2011]. 